\title{
Association of the Maternal Folic Acid Supplementation with the Autism Spectrum Disorder: A Systematic Review
}

\section{Associação da suplementação de ácido fólico materno com o transtorno do espectro do autismo: uma revisão sistemática}

\author{
Adalberto Cruz Sampaio ${ }^{10}$ Francisco Facundo de Matos Neto ${ }^{10}$ Lucas de Lucena Lopes ${ }^{10}$ \\ Ítalo Marcelo Maia Marques ${ }^{10}$ Ravel Moreira Tavares $^{10}$ Marcus Vinicius de Macedo Fernandes ${ }^{10}$ \\ Maria Raquel Vieira da Silva Teixeira ${ }^{20}$ Alessandra Bezerra de Brito ${ }^{30}$ Andrea Couto Feitosa ${ }^{3(0)}$ \\ Tarciana Oliveira Guedes ${ }^{4}$ Magaly Lima Mota ${ }^{4}$ (을
}

\footnotetext{
${ }^{1}$ Department of Medicine, Faculdade de Medicina Estácio de Juazeiro do Norte, Barbalha, CE, Brazil

2 Department of Nursing, Faculdade Integrada de Araguatins, Juazeiro do Norte, CE, Brazil

${ }^{3}$ Department of Nursing, Centro Universitário Dr. Leão Sampaio, Crato, CE, Brazil

${ }^{4}$ Department of Nursing, Centro Universitário Dr. Leão Sampaio, Juazeiro do Norte, CE, Brazil
}

Rev Bras Ginecol Obstet 2021;43(10):775-781.

\author{
Address for correspondence Magaly Lima Mota, PhD, Avenue Leão \\ Sampaio, 400, 63040-000, Campus Health, Lagoa Seca, Juazeiro do \\ Norte, CE, Brazil (e-mail: magaly@leaosampaio.edu.br).
}

\begin{abstract}
Keywords

- autistic spectrum disorder

- folic acid

- pregnancy

- supplementation

Objective To analyze the scientific production regarding maternal folic acid (FA) supplementation and its relationship with autistic spectrum disorder (ASD).

Data Sources We performed unrestricted electronic searches in the BIREME virtual bank, Virtual Health Library (VHL) and Medical Literature Analysis and Retrieval System Online (MEDLINE/PubMed) databases.

Selection of Studies For sample selection, articles that met the proposed objectives were included, published in English, Spanish and Portuguese, the use of Health Sciences Descriptors (DeCS): autistic OR autism AND autism spectrum disorder AND folic acid, AND, with the use of the Medical Subject Headings (MeSH): autistic OR autism AND autistic spectrum disorder AND folic acid.

Data Collection Data extraction was performed by the reviewers with a preestablished data collection formulary.

Data Synthesis The Preferred Reporting Items for Systematic Review and MetaAnalysis Protocols (PRISMA-P) was used based on a checklist with 27 items and a 4-step flowchart.
\end{abstract}

received

October 17, 2020

accepted

July 7, 2021
DOI https://doi.org/ 10.1055/s-0041-1736298. ISSN 0100-7203. (c) 2021. Federação Brasileira de Ginecologia e Obstetrícia. All rights reserved.

This is an open access article published by Thieme under the terms of the Creative Commons Attribution License, permitting unrestricted use, distribution, and reproduction so long as the original work is properly cited. (https://creativecommons.org/licenses/by/4.0/)

Thieme Revinter Publicações Ltda., Rua do Matoso 170, Rio de Janeiro, RJ, CEP 20270-135, Brazil 


\section{Resumo}

\author{
Palavras-chave \\ - transtorno do \\ espectro autista \\ - ácido fólico \\ - gravidez \\ - suplementação
}

Results A total of 384 articles was found by the search strategies, of which 17 were eligible following the pre-established criteria. The main findings of the present review point to maternal FA supplementation in the pre-conception period and beginning of pregnancy as a protective effect in relation to ASD, which should be indicated in this period as prevention to the problem.

Conclusion According to the research analyzed, more studies are necessary to know its effects on pregnancy, since the consumption of excessive FA may not be innocuous.

Objetivo Analisar a produção científica a respeito da suplementação de ácido fólico (AF) materno e sua relação com o transtorno do espectro autista (TEA).

Fontes de Dados Realizamos buscas eletrônicas irrestritas nas bases de dados do banco virtual BIREME, Biblioteca Virtual em Saúde (VHL) e Medical Literature Analysis and Retrieval System Online (MEDLINE / PubMed).

Seleção dos Estudos Incluímos os artigos publicados em inglês, espanhol e português, com o uso dos DeCS: autistic OR autism AND autism spectrum disorder AND folic acid, e com o uso dos Medical Subject Headings (MeSH, na sigla em inglês): autistic OR autism AND Autistic Spectrum Disorder AND folic acid “.

Coleta de Dados A extração de dados foi realizada pelos revisores com um formulário de coleta de dados pré-estabelecido.

Síntese dos Dados Foram usados os itens de relatório preferidos para protocolos de revisão sistemática e meta-análise (PRISMA-P) com base em uma lista de verificação com 27 itens e um fluxograma de 4 etapas.

Resultados Foram encontrados 384 artigos pelas estratégias de busca, dos quais 17 eram elegíveis segundo os critérios pré-estabelecidos. Os principais achados da presente revisão apontam para a suplementação de AF materno no período de preconcepção e início da gravidez como efeito protetor em relação ao TEA, que deve ser indicada neste período como prevenção do problema.

Conclusão De acordo com as pesquisas analisadas, mais estudos são necessários para conhecer seus efeitos sobre a gravidez, uma vez que o consumo excessivo de AF pode não ser inócuo.

\section{Introduction}

Autism Spectrum Disorder (ASD) is characterized by persistent deficits in social interaction and communication, with the presence of repetitive interests and activities. Considered as a neurodevelopmental disorder, it can manifest with extremely variable phenotypes, from severely compromised individuals to independent individuals. ${ }^{1,2}$

The World Health Organization estimates that 1 in 160 children has ASD. The use of preconception folic acid (FA) should be indicated at least 2 months before conception and in the $1^{\text {st }} 2$ months of pregnancy, as it has a protective effect against open defects of the neural tube. ${ }^{3}$

Since 2004, in Brazil, the Ministry of Health, through the National Health Surveillance Agency (ANVISA, in the Portuguese acronym), adopted the Collegiate Directorate Resolution (RDC, in the Portuguese acronym) No. 344 of December 13, 2002, establishing mandatory FA fortification in wheat flour and corn to reduce the prevalence of maternal anemia and defects of the neural tube. This fortification of synthetic FA may have generated a population group with high serum levels of nonmetabolized FA. This finding occurs when $>200 \mathrm{mg} /$ day is ingested. ${ }^{4}$

The theme has great importance in the social context because it involves the patient, their family, the state, and the multiprofessional action, which makes its study fundamental to guarantee the practice of evidence-based health care. The objective of the present review is to describe the relationship between maternal FA supplementation and ASD, according to scientific publications.

\section{Methods}

This is a qualitative exploratory study, of the metasynthesis type. The search for data was performed between February 2018 and February 2020, based on the BIREME virtual bank, the Virtual Health Library (VHL), and the Medical Literature Analysis and Retrieval System Online (MEDLINE/PubMed) databases.

The inclusion criteria were: original articles, systematic reviews, available in full, free of charge, studies with human beings, published in English, Spanish, and Portuguese, 


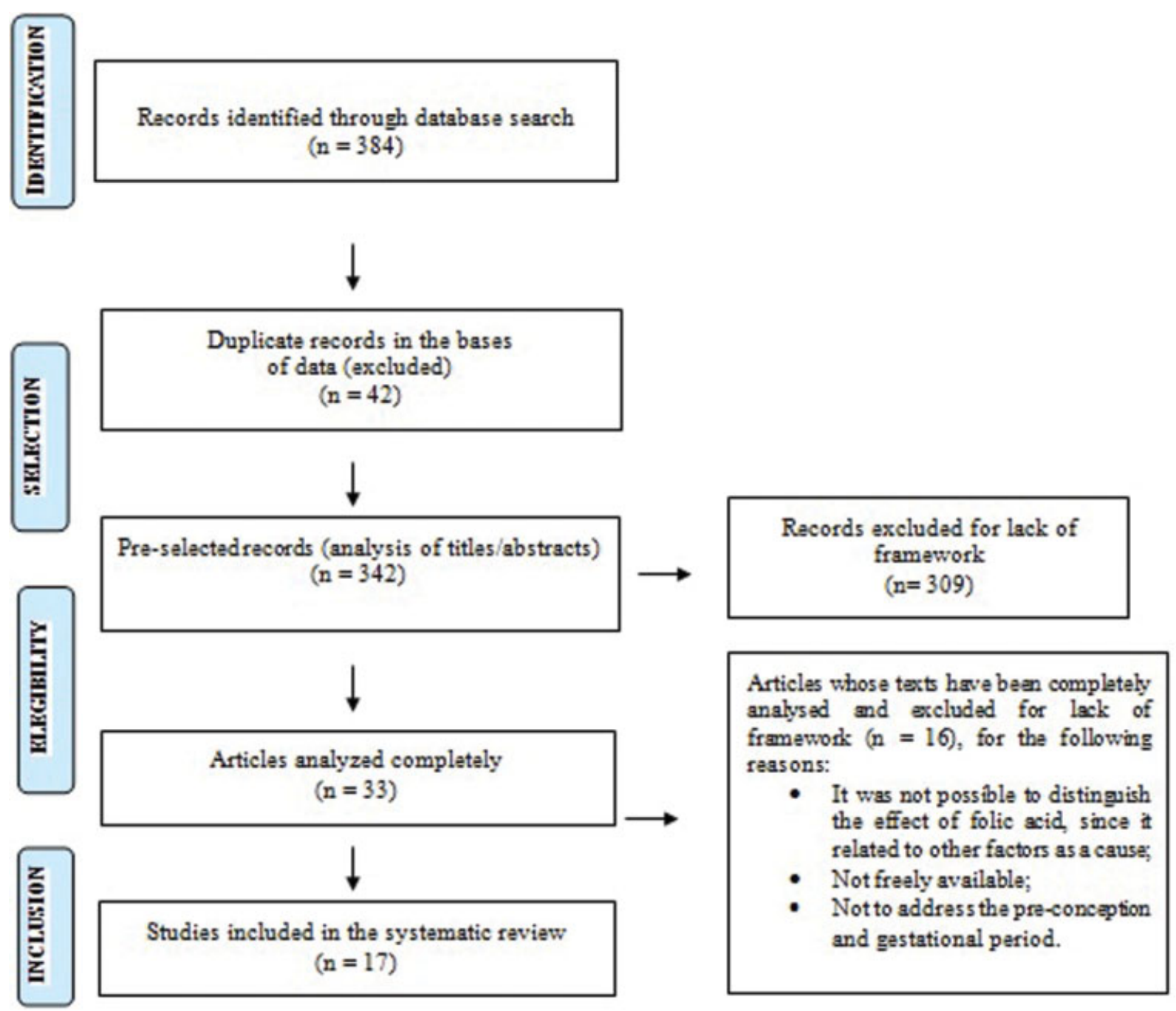

Fig. 1 Flowchart of eligible items. Source: Flowchart prepared according to PRISMA recommendations.

which addressed the use of FA related to the occurrence of ASD.

The exclusion criteria used in this study start with free availability, that is, studies published on non-free platforms were excluded from this research. The year of publication was also one of the criteria used in this review, these were strictly maintained between the years 2013 to 2020, another criterion used was the thematic, to exclude all works in which their title and later their summary dealt with a different theme of the association between maternal FA supplementation and ASD.

Studies that depict ASD associated with other drugs or other factors that do not correspond to consumption of supplemental FA were excluded from the study, or those that deal with the consumption of FA without associating it with ASD. The period in which FA is used was also one of the criteria used in the present review, and all those dealing with the consumption of FA at different periods of the periconceptional and gestational period were excluded. Studies with animals and those that portrayed other subjects outside the area of interest of the present research were excluded.

The operationalization of the search for data collection was performed in the BIREME database using Health Science
Descriptors (DeCS) linked to Boolean operators and using quotation marks in compound words, (autistic OR autism) AND ("autism spectrum disorder") AND ("folic acid"). In the PubMed database, the search was performed in English using Medical Subject Headings (MeSH) linked to Boolean operators and quotes in compound words, (autistic OR autism) AND ("autistic spectrum disorder") AND ("folic acid").

The Preferred Reporting Items for Systematic Review and Meta-Analysis Protocols (PRISMA-P) was used based on a checklist with 27 items and a 4-step flowchart. ${ }^{5}$ In the present review, the acronym PICO (Patients; Intervention; Comparison; Outcome) was also used to construct the guiding question of the study and to perform the bibliographic search. For the presentation of eligibility criteria, the PRISMA and the table containing information such as authors, year of publication, place and results were used (-Fig. 1).

\section{Results}

According to the search strategy adopted, 220 articles were found at BIREME and 164 at PubMed, totaling 384 selected 


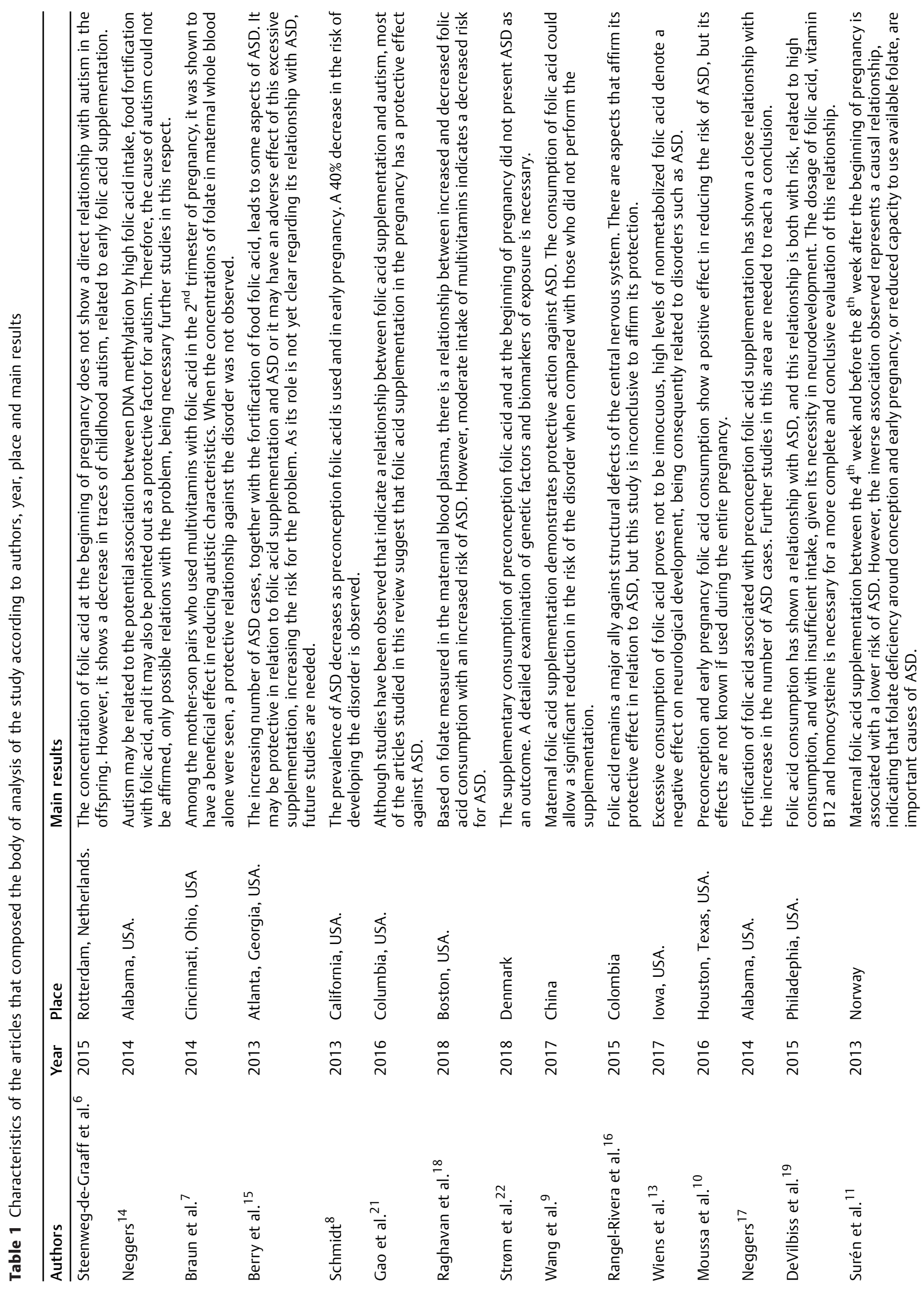


articles, as seen in - Fig. 1, and the studies are presented in tabular form, as seen in - Table 1 .

The main result of the present review is that the use of FA in the preconception period and in the beginning of pregnancy is effective in preventing ASD. Therefore, early supplementation with FA is beneficial for neurodevelopment and, consequently, acts on the prevention of ASD. The consumption of additional FA at an early stage should be indicated, because in addition to preventing $\sim 70 \%$ of neural tube defects cases, it is associated with a protective effect in relation to ASD.

It was also found that excess FA consumption and the gestational period in which it is used can have a negative influence on the occurrence of ASD. Too much intake can be observed, since FA, in addition to being consumed in the usual diet, can also be added in the form of oral supplementation, which, associated with the extended time of use, demonstrates a causative effect for the disorder.

Many studies addressed in the present review bring inconclusive results regarding the effect of FA in relation to ASD, indicating the need for future investigations of maternal FA serum levels and also a detailed investigation regarding its consumption from the $2^{\text {nd }}$ trimester of pregnancy, a period considered a risk for its use, in relation to the disorder. All this is relevant, so that optimal doses are indicated according to individual needs and maternal nutritional deficiency.

Of the 15 studies evaluated, 8 were unable to safely determine the effects caused by FA. The majority found that there is an effect on neurodevelopment and even observed a relationship with ASD, but in a contradictory way, which may be protective or even cause the problem. They also point out the need for further studies and that an evaluation of FA in the blood plasma of the mother should be performed to analyze its possible indication, in optimal dose and time.

\section{Discussion}

After the analysis of the eligible articles and following the already defined method, three thematic categories emerged: FA as a protection to ASD, increased risk of ASD in relation to excessive use of FA, and inconclusive association between FA consumption and ASD.

\section{Folic Acid as Protection against Autism Spectrum Disorder}

Studies carried with children diagnosed with ASD whose mothers used FA in the 6 weeks before and after conception pointed to the protective effect of preconception FA and the occurrence of ASD. ${ }^{6-8}$ Folic acid consumption is related to a decrease in the occurrence of ASD when compared with other mothers who did not have the supplementation. ${ }^{9,10}$ Corroborating in the study, the nonuse or deficiency in the folate metabolism in this same period can be pointed out as a cause for the development of autism disorder. ${ }^{11}$

A study was conducted in a Chinese population with a total of 416 children with ASD and 201 children with typical 
development (TD). It concluded that children born to mothers without FA and micronutrient supplementation during pregnancy exhibited more severe social cognitive impairment, such as social communication, behavioral mannerisms, delays in developing raw and adaptive motor behavior, and gastrointestinal problems than children born to mothers who used FA and micronutrient supplements, demonstrating the need for micronutrient supplementation during pregnancy and periconception. ${ }^{12}$

In this category, it is clear that FA can be considered a protector for autism, especially when used in the preconception period and at the beginning of pregnancy, since research has shown that it reduces the risk of autism in the offspring. This beneficial effect cannot be confirmed if consumed during the rest of the course of pregnancy. It should be noted that many studies point to FA supplementation as having a beneficial effect in relation to ASD, since 8 of the 15 analyzed studies point to this effect.

\section{Increased Risk of ASD in Relation to Excessive Use of Folic Acid}

Studies show that maternal FA supplementation, together with food fortification, has resulted in a population with superior parameters of AF than expected, and with an excess of nonmetabolized folate in the body. This may be associated with an increasing number of ASD cases. ${ }^{13}$

\section{Inconclusive Association between Folic Acid Consumption and Autism Spectrum Disorder}

It is still too early to reach a conclusion on the association between FA consumption and ASD. Studies show its protective effect against ASD, but others intrigue us with their investigations of alterations in the metabolic pathways of maternal folate, its potential role in DNA methylation through high maternal FA intake and its relationship with autistic traits. Finding the optimal level of maternal FA intake is difficult, but it may be the answer to these hypotheses. ${ }^{14}$

The beneficial or harmful effect of FA on ASD cannot be stated. This requires intensified studies to discover the relationship of nutrition in different populations and the association with food fortification and additional FA supplementation. ${ }^{15,16}$ The increase in the number of ASD cases may be linked to several factors, such as changing diagnostic criteria, increased information, and excess FA consumed by women of childbearing age. ${ }^{17}$

Supplementation with periconceptional FA reduced neural tube defects by up to $70 \%$ and resulted in fortification of cereal products in several countries. The recommendation was that all women of childbearing age should consume $400 \mu \mathrm{g} /$ day of FA. It was also observed that the metabolism of maternal folate can vary between women, which may be involved with the increase in the number of cases of ASD.

Based on postpartum maternal blood samples, folate and vitamin B12 were analyzed in mothers who reported multivitamin supplement consumption at least in the $3^{\text {rd }}$ trimester of pregnancy. The diagnosis of ASD was observed through electronic medical records. The results can be understood as a " $U$ " format, where the increased risk for ASD is at both extremes, when the supplement was consumed in excess and when it was consumed in small amounts. In contrast, moderate supplementation showed a protective effect in relation to ASD. ${ }^{18}$

The maternal folate status may be related to ASD. Insufficient FA consumption may lead to hypomethylation of DNA, which is associated with neurodevelopment. It has also been found in some studies that FA consumption can be considered protective for autism.

The author indicates that repeated biological measurements of folate, vitamin B12 and homocysteine during the $1^{\text {st }}$ trimester of pregnancy are necessary, as well as genetic variants relevant to folate involved in carbon metabolism, and the epigenetic mechanisms. ${ }^{19}$

The relationship of ASD with maternal use of micronutrients such as iron, zinc, vitamin D and AF were evaluated, and it was observed that the AF shows contradictory effects in relation to the TEA, which, in some studies, is presented as a protective effect and, in others, as causal effects. Thus, it was not possible to demonstrate whether or not there is a relationship between PA supplementation and ASD. Another finding in relation to ASD involves its relationship with glutathione, a product of the methionine cycle that depends on FA and B12, this element is involved in neuroprotection against oxidative stress and neuroinflammation in the brain. Research shows that glutathione is deficient in children with autism when compared with children with typical development. ${ }^{20}$

\section{Conclusion}

The use of FA in the preconception period and in the beginning of pregnancy is effective in preventing ASD. Therefore, early supplementation with FA is beneficial for neurodevelopment and, consequently, acts on the prevention of ASD. The present study deals strictly with the consumption of FA with the development of ASD, and the action of FA in the treatment of other neurological problems has not been reviewed. The study also did not aim to associate the use of FA with other drugs. The present study recommends that new investigations be performed to identify optimal doses and identify whether FA consumption from the $2^{\text {nd }}$ trimester can really be associated with the increase in the number of new cases of ASD as mentioned by some studies in the present review.

\section{Contributors}

All the authors participated in the concept and design of the study; in the analysis and interpretation of data; in the draft or revision of the manuscript; and they have approved the manuscript as submitted. All authors are responsible for the reported research.

\section{Conflict of Interests}

The authors have no conflict of interests to declare.

\section{Acknowledgments}

We thank all the collaborators in the present study for their commitment and dedication. 


\section{References}

1 Posar A, Visconti P. Sensory abnormalities in children with autism spectrum disorder. J Pediatr (Rio J). 2018;94(04):342-350. Doi: 10.1016/j.jpedp.2017.11.009

2 Griesi-Oliveira K, Sertié AL. Autism spectrum disorders: an updated guide for genetic counseling. Einstein (Sao Paulo). 2017;15(02):233-238. Doi: 10.1590/S1679-45082017RB4020

3 Ministério da Saúde. Secretaria de Atenção à Saúde. Departamento de Atenção Básica. [Attention to low risk prenatal care] [Internet]. Brasília (DF): Publisher of the Ministry of Health 2013 [cited 2018 Feb 25]. Available from: http://189.28.128.100/dab/docs/portaldab/publicacoes/caderno_32.pdf. Portuguese.

4 Espolador GM, Jordão BA, Cardoso MG, Sabino AM, Tavares BB. Identificação dos fatores associados ao uso da suplementação do ácido fólico na gestação. Rev Enferm Cent Oeste Min. 2015;5(02): 1552-1561. Doi: 10.19175/recom.v0i0.766. Accessed February 14,2020 at http://www.seer.ufsj.edu.br/index.php/recom/ article/view/766/857

5 Shamseer L, Moher D, Clarke M, Ghersi D, Liberati A, Petticrew M, et al; PRISMA-P Group. Preferred reporting items for systematic review and meta-analysis protocols (PRISMA-P) 2015: elaboration and explanation. BMJ. 2015;350:g7647. Doi: 10.1136/bmj. g7647

6 Steenweg-de Graaff J, Ghassabian A, Jaddoe VW, Tiemeier H, Roza SJ. Folate concentrations during pregnancy and autistic traits in the offspring. The Generation R Study. Eur J Public Health. 2015; 25(03):431-433. Doi: 10.1093/eurpub/cku126

7 Braun JM, Froehlich T, Kalkbrenner A, Pfeiffer CM, Fazili Z, Yolton $\mathrm{K}$, et al. Brief report: are autistic-behaviors in children related to prenatal vitamin use and maternal whole blood folate concentrations? J Autism Dev Disord. 2014;44(10):2602-2607. Doi: 10.1007/s10803-014-2114-X

8 Schmidt RJ. Maternal folic acid supplements associated with reduced autism risk in the child. Evid Based Med. 2013;18(06): e53. Doi: 10.1136/eb-2013-101311

9 Wang M, Li K, Zhao D, Li L. The association between maternal use of folic acid supplements during pregnancy and risk of autism spectrum disorders in children: a meta-analysis. Mol Autism. 2017;8:51. Doi: 10.1186/s13229-017-0170-8

10 Moussa HN, Hosseini Nasab S, Haidar ZA, Blackwell SC, Sibai BM. Folic acid supplementation: what is new? Fetal, obstetric, long- term benefits and risks. Future Sci OA. 2016;2(02):FSO116. Doi: 10.4155/fsoa-2015-0015

11 Surén P, Roth C, Bresnahan M, Haugen M, Hornig M, Hirtz D, et al. Association between maternal use of folic acid supplements and risk of autism in children. JAMA. 2013;309(06):570-577. Doi: 10.1001/jama.2012.155925

12 Tan M, Yang T, Zhu J, Li Q Lai X, Li Y, et al. Maternal folic acid and micronutrient supplementation is associated with vitamin levels and symptoms in children with autism spectrum disorders. Reprod Toxicol. 2020;91:109-115. Doi: 10.1016/j.reprotox.2019.11.009

13 Wiens D, DeSoto MC. Is high folic acid intake a risk factor for autism? A review. Brain Sci. 2017;7(11):149. Doi: 10.3390/brainsci7110149

14 Neggers Y. The relationship between folic acid and risk of autism spectrum disorders. Healthcare (Basel). 2014;2(04):429-444. Doi: $10.3390 /$ healthcare2040429

15 Berry RJ, Crider KS, Yeargin-Allsopp M. Can we change the risk of autism? JAMA. 2013;309(06):611-613. Doi: 10.1001/ jama.2013.198

16 Rangel-Rivera DA, Osma-Zambrano SE. Consumo de ácido fólico en el embarazo y reducción del riesgo de transtornos del espectro autista. Med UIS. 2015;28(03):327-336. Accessed on March 1, 2020 at: https://pesquisa.bvsalud.org/portal/resource/pt/lil776289

17 Neggers YH. Increasing prevalence, changes in diagnostic criteria, and nutritional risk factors for autism spectrum disorders. ISRN Nutr. 2014;2014:514026. Doi: 10.1155/2014/514026

18 Raghavan R, Riley AW, Volk H, Caruso D, Hironaka L, Sices L, et al. Maternal multivitamin intake, plasma folate and vitamin $B_{12}$ levels and autism spectrum disorder risk in offspring. Paediatr Perinat Epidemiol. 2018;32(01):100-111. Doi: 10.1111/ ppe.12414

19 DeVilbiss EA, Gardner RM, Newschaffer CJ, Lee BK. Maternal folate status as a risk factor for autism spectrum disorders: a review of existing evidence. Br J Nutr. 2015;114(05):663-672. Doi: $10.1017 /$ S0007114515002470

20 Altamimi M. Could autism be associated with nutritional status in the Palestinian population? The outcomes of the Palestinian micronutrient survey. Nutr Metab Insights. 2018; 11:1178638818773078. Doi: 10.1177/1178638818773078 